\title{
EFFECT OF ENZYME SUPPLEMENTATION ON PERFORMANCE OF BROILER CHICKS
}

\author{
H.F.A.Motawe, T.M.El-Afifi, M.S.Haready and A.H.M.Gomaa \\ Central Lab. for Food and Feed (CLFF), A.R.C, 588 Orman, Giza, Egypt
}

ABSTRACT

An experiment was conducted to study the effect of adding a commercial enzyme (Nutrase Xylan) to diets of male broiler chicks on their productive performance. The enzyme is of bacterial origin (Bacilluis subtilis) which contains Endo-1,4- $\beta$-xylanase combined with $\alpha$-amylase. The enzyme was added to a balanced corn/soy diet at two levels, $(0.05 \%$ and $0.1 \%)$. The experiment was designed to test two different energy levels against a normal energy requirement (recommended oil addition).

A total number of 150 one-day old male Ross chicks was individually weighed and randomly distributed among five groups of 30 chicks each. The control was fed a starter-grower diet (0-28 day old) which contained $22 \% \mathrm{CP}$ and $3100 \mathrm{Kcal} \mathrm{ME} / \mathrm{kg}$ feed, $1.72 \%$ oil and a finisher diet (28-42 day old) which contained 19\% CP and 3200 Kcal ME/kg feed and $3.51 \%$ oil. The control group were fed dites which contained normal energy, 3100 and 3200 Kcal ME for starter/grower and finisher, respectiviley. The Control group compared with four treated groups as follows: En 1/0.05 (3040 and $3060 \mathrm{Kcal}$ $\mathrm{ME} / \mathrm{Kg}$ diet) with $0.05 \%$ enzyme; En 1/0.10 same as En 1/0.05 but with $0.10 \%$ enzyme; En 2/0.05 (2970 and 2920 Kcal)l with $0.05 \%$ enzyme and En 2/0.10 same as En 2/0.05 but with $0.10 \%$ enzyme.

/The results obtained were as follow:

- No significant difference was found between supplementation of enzyme at $0.05 \%$ or $0.1 \%$ levels over all the experiment.

- No significant increase in body weight (BW) between the control group and En1 groups in either of starter/grower or finisher: $953 \mathrm{~g}$ vs. $946 \mathrm{~g}$ and $945 \mathrm{~g} ; 1791 \mathrm{~g}$ vs. $1764 \mathrm{~g}$ and $1743 \mathrm{~g}$, respectively. No significant differences in BW were found between both En 2 groups overall the experiment.

- Feed intake (FI) showed no significant difference between the control group and En1 treated groups in starting/growing and finishing periods. In addition, in the whole period, no significant difference in FI was found between En 2 groups.

- Weight gain (WG) showed no significant difference in starting/ growing and finishing periods between the control group and En1 groups (911g vs. 904 and $903 \mathrm{~g}$ ). No significant difference in WG was found between En2 treated groups through out the experiment.

- The enzyme treated groups containing low energy levels (En 1/0.05 and En 1/0.1) gave similar results of body weight as obtained from the control group (normal energy or recommended oil requirement). However, starter/grower and finisher diets had $1.99 \%$ and $4.4 \%$ reduction in ME/kg values (DM), respectively.

Key words: Broilers, feed enzymes, energy restriction, vegetable oil, chick performance

Fayoum J. Agric. Res. \& Dev., Vol.19, No.2, July, 2005 


\section{INTRODUCTION}

Poultry feeds depend mostly on plant feed ingredients. Consequently, a considerable quantity of water soluble non-starch polysaccharides (NSPs) exists as the major antinutritional factor in cereals and other plant materials, (Campbell and Bedford 1992; Bedford 1995; Jaroni et al 1999; Zhang et al 2000; Zyla et al 2000; Zhang et al 2001; Benamrouche 2002 and Brenes et al 2002).

Poultry do not digest NSP compounds similarly to other monogastric animals such as pigs and rats,(Huisman and Tolman 1992 and Jorgensen $\boldsymbol{e t}$ al 1996). Therefore, the proper choice of exogenous enzymes are needed, (Malathi and Devegowda 2001; Bedford and classen 1992; Alam et al 2003 and Yakout et al 2003).

The supplementation of feed enzymes, i.e. xylanase and /or $\beta$-glucanase, into the basal diet are able to release the available energy stored in NSPs (Rotter et al 1990;Salobir 1998;Salobir et al 2000;Kocher et al 2000; Mathlouthi et al 2002 and Speers 2002).

The objective of this study was to investigate the efficacy of dietary energy levels as supplemented with two different levels of a commercial enzyme preparation, on the performance of male broiler chicks.

\section{MATERIALS AND METHODS}

The exogenous enzyme used in the current study is a commercial preparation (Nutrase Xylam) produced from Bacillus subtilis containing Endo$1,4-\beta$-xylanase and $\alpha$-amylase. The feeding program was designed to supplement two levels of this enzyme preparation i.e. at $0.05 \%$ and $0.10 \%$ of the feed. Two levels of energy were used. i.e. vegetable oil in starter-grower broiler diets was added at the levels of $1.72 \%$ and $0.86 \%$, respectively, and in the finisher diets at the levels of $3.51 \%$ and $1.755 \%$, respectively.

Total number of 150 one-day old male Ross chicks were obtained from a commercial hatchery and were randomly distributed among five treated groups (each of 30 chicks). Birds were brooded in a washed fumigated brooder house using electric heaters to keep the required temperature during brooding period while light was provided 24 hrs daily throughout the experimental period. The chicks were individually weighed, feed and water were provided ad-libitum.

Control group: Normal energy content

$$
\text { - } 3100 \mathrm{Kcal} / \mathrm{kgDM} \text { for the starter/grower diet }
$$

- $3200 \mathrm{Kcal} / \mathrm{kg} \mathrm{DM}$ for the finisher diet

The control group was fed a starter-grower diet from day-old up to 28 days of age, Table (1), which containing $22 \% \mathrm{CP}$ and $3100 \mathrm{Kcal} \mathrm{ME} / \mathrm{kg}$ and $1.72 \%$ vegetable oil. After that chicks were fed a finisher diet from $29^{\text {th }}$ day till $42^{\text {nd }}$ day, Table (2), containing $19 \% \mathrm{CP}$ and $3200 \mathrm{Kcal} \mathrm{ME} / \mathrm{kg}$ and $3.51 \%$ vegetable oil. The control group was compared with the following four treated groups:

Energy 1/0.05:

- $3040 \mathrm{Kcal} / \mathrm{kg} \mathrm{DM}$ for the starter/grower diet $+0.05 \%$ enzyme

- $3060 \mathrm{Kcal} / \mathrm{kg} \mathrm{DM}$ for the finisher diet $+0.05 \%$ enzyme

A starter-grower diet, Table (1), containing 22\% CP and $3040 \mathrm{Kcal}$ $\mathrm{ME} / \mathrm{kg}$ and $0.86 \%$ vegetable oil. This quantity of oil represents half of oil for the control group, then chicks were fed a finisher diet, Table (2), containing $19 \% \mathrm{CP}$ and $3060 \mathrm{Kcal} \mathrm{ME} / \mathrm{kg}$, supplemented with 50mg enzyme and $1.755 \%$ vegetable oil. This quantity of oil represents half of oil of the control group.

Fayoum J. Agric. Res. \& Dev., Vol.19, No.2, July, 2005 
EFFECT OF ENZYME SUPPLEMENTATION ON PERFORMANCE.....

Energy 1/0.1 :

- $3040 \mathrm{Kcal} / \mathrm{kg} \mathrm{DM}$ for the starter/grower diet $+0.1 \%$ enzyme

Energy 2/0.05:

- $3060 \mathrm{Kcal} / \mathrm{kg} \mathrm{DM}$ for the finisher $+0.1 \%$ enzyme

- $2970 \mathrm{Kcal} / \mathrm{kg} \mathrm{DM}$ for the starter/grower diet $+0.05 \%$ enzyme

- $2920 \mathrm{Kcal} / \mathrm{kg} \mathrm{DM}$ for the finisher diet $+0.05 \%$ enzyme

A starter-grower diet, Table (1), containing 22\% CP, $2970 \mathrm{Kcal} \mathrm{ME} / \mathrm{kg}$, supplemented with 50mg enzyme and no added vegetable oil, then fed a finisher diet, Table (2), containing $19 \% \mathrm{CP}, 2920 \mathrm{Kcal} \mathrm{ME} / \mathrm{kg}$ feed, supplemented with 50mg enzyme and no added vegetable oil.

Energy 2/0.1 :

- $2970 \mathrm{Kcal} / \mathrm{kg} \mathrm{DM}$ for the starter/grower diet $+0.1 \%$ enzyme

- $2920 \mathrm{Kcal} / \mathrm{kg} \mathrm{DM}$ for the finisher diet $\quad+0.1 \%$ enzyme

The same diet like Energy 2/0.05 but supplemented with $100 \mathrm{mg}$ enzyme preparation.

The chicks were weighed individually on $28^{\text {th }}$ and $42^{\text {nd }}$ day of age. Feed intake was recorded throughout the periods on a group basis. The feed conversion ratio (unit feed/unit gain) was calculated.

The data were statistically analysed using the general linear model for analysis of variance (SAS Institute, 1990). Significant differences among treatments means were separated by Duncan's new multiple range test (Duncan, 1955).

Table (1): Composition of experimental diets for broilers from 0-28 days of age (starter-grower period).

\begin{tabular}{|l|c|c|c|c|c|}
\hline \multicolumn{1}{|c|}{ Ingredients, \% } & Control & En1/ 0.05 & En1/0.1 & En 2/0.05 & En 2/0.1 \\
\hline Yellow corn & 62.68 & 62.68 & 62.68 & 62.68 & 62.68 \\
\hline Soybean meal & 25.50 & 25.50 & 25.50 & 25.50 & 25.50 \\
\hline Corn gluten meal & 6.00 & 6.00 & 6.00 & 6.00 & 6.00 \\
\hline Di-Ca-ph & 2.05 & 2.05 & 2.05 & 2.05 & 2.05 \\
\hline Limestone & 0.68 & 0.68 & 0.68 & 0.68 & 0.68 \\
\hline Vit\&Min.mixture & 0.40 & 0.40 & 0.40 & 0.40 & 0.40 \\
\hline Salt & 0.30 & 0.30 & 0.30 & 0.30 & 0.30 \\
\hline L-lysine HCl & 0.44 & 0.44 & 0.44 & 0.44 & 0.44 \\
\hline DL-methionine & 0.23 & 0.23 & 0.23 & 0.23 & 0.23 \\
\hline Vegetable oil & 1.72 & 0.86 & 0.86 & 000 & 000 \\
\hline Sawdust & 000 & 0.81 & 0.76 & 1.67 & 1.62 \\
\hline Enzyme & 000 & 0.05 & 0.10 & 0.05 & 0.10 \\
\hline Total & 100.00 & 100.00 & 100.00 & 100.00 & 100.00 \\
\hline Calculated values: & & & & & \\
\hline CP & 22.00 & 22.00 & 22.00 & 22.00 & 22.00 \\
\hline ME ( kcal/kg) & 3100 & 3040 & 3040 & 2970 & 2970 \\
\hline Ca & 0.97 & 0.97 & 0.97 & 0.97 & 0.97 \\
\hline Avail. P & 0.50 & 0.50 & 0.50 & 0.50 & 0.50 \\
\hline Methionine & 0.52 & 0.52 & 0.52 & 0.52 & 0.52 \\
\hline Meth+Cys & 0.94 & 0.94 & 0.94 & 0.94 & 0.94 \\
\hline Lysine & 1.30 & 1.30 & 1.30 & 1.30 & 1.30 \\
\hline
\end{tabular}

* Vitamin-mineral mixture supplied per kg of diet:Vit A=12000 IU;Vit D3= $2000 \mathrm{IU}$; Vit

$\mathrm{E}=10 \mathrm{mg}$;Vit K3=2mg;VitB1=1mg;VitB2-5mg;B6=1.5mg;VitB12=10 $\mu \mathrm{g}$; Biotin=50 $\mu$ g;Choline chloride $=500 \mathrm{mg} ;$ Pantothenic acid $=10 \mathrm{mg} ;$ Niacin $=30 \mathrm{mg} ;$ Folic

acid $=1 \mathrm{mg} ;$ Manganese $=60 \mathrm{mg} ;$ zinc $=50 \mathrm{mg} ;$ Iron=30mg;Copper $=10 \mathrm{mg} ;$ Iodine $=1 \mathrm{mg} ;$ Selenium $=0.1$

$\mathrm{mg}$ and Cobalt $=0.1 \mathrm{mg}$.

Fayoum J. Agric. Res. \& Dev., Vol.19, No.2, July, 2005 
Table (2): Composition of the experimental diets for broilers from 28-42 days of age (Finisher period).

\begin{tabular}{|l|c|c|c|c|c|}
\hline \multicolumn{1}{|c|}{ Ingredient, \% } & Control & En 1/0.05 & En 1/0.1 & En 2/0.05 & En 2/0.1 \\
\hline Yellow corn & 67.997 & 67.997 & 67.997 & 67.997 & 67.997 \\
\hline Soybean meal & 20.800 & 20.800 & 20.800 & 20.800 & 20.800 \\
\hline Corn gluten meal & 4.00 & 4.00 & 4.00 & 4.00 & 4.00 \\
\hline Di-Ca-Ph & 1.73 & 1.73 & 1.73 & 1.73 & 1.73 \\
\hline Lime stone & 0.57 & 0.57 & 0.57 & 0.57 & 0.57 \\
\hline Vit\&Min.mixture & 0.4 & 0.4 & 0.4 & 0.4 & 0.4 \\
\hline Salt & 0.3 & 0.3 & 0.3 & 0.3 & 0.3 \\
\hline L-lysine HCl & 0.454 & 0.454 & 0.454 & 0.454 & 0.454 \\
\hline Dl-methionine & 0.239 & 0.239 & 0.239 & 0.239 & 0.239 \\
\hline Vegetable oil & 3.51 & 1.755 & 1.755 & 000 & 000 \\
\hline Sawdust & 000 & 1.705 & 1.655 & 3.46 & 3.41 \\
\hline Enzyme & 000 & 0.05 & 0.10 & 0.05 & 0.10 \\
\hline Total & 100.00 & 100.00 & 100.00 & 100.00 & 100.00 \\
\hline Calculated values: & & & & & \\
\hline CP & 19.00 & 19.00 & 19.00 & 19.00 & 19.00 \\
\hline ME (kcal/kg) & 3200 & 3060 & 3060 & 2920 & 2920 \\
\hline Calcium & 0.85 & 0.85 & 0.85 & 0.85 & 0.85 \\
\hline Avail.P & 0.44 & 0.44 & 0.44 & 0.44 & 0.44 \\
\hline Methinine & 0.47 & 0.47 & 0.47 & 0.47 & 0.47 \\
\hline Meth+Cys & 0.85 & 0.85 & 0.85 & 0.85 & 0.85 \\
\hline Lysine & 1.13 & 1.13 & 1.13 & 1.13 & 1.13 \\
\hline
\end{tabular}

* Vitamin-mineral mixture supplied per kg of diet:Vit A=12000 IU;Vit D3= 2000 IU; Vit

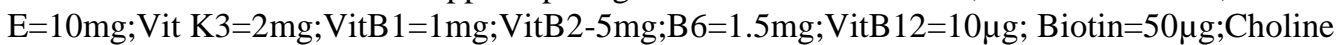
chloride $=500 \mathrm{mg} ;$ Pantothenic acid=10mg; Niacin=30mg; Folic acid=1 mg; Manganese $=60 \mathrm{mg}$;

Zinc $=50 \mathrm{mg}$;Iron=30mg;Copper $=10 \mathrm{mg} ;$ Iodine $=1 \mathrm{mg} ;$ Selenium $=0.1 \mathrm{mg}$ and Cobalt $=0.1 \mathrm{mg}$.

\section{RESULTS AND DISCUSSION}

The effects of feeding enzyme on broiler performance during startergrower (0-28 days), finisher (29-42 days) and the whole period (0-42 days) are shown in Tables 3-5.

At the starting-growing period, from the beginning of the trial up to 28 days of age, the performance results are summarized in Table (3):

Table (3): The effect of enzyme supplementation on broiler performance during the starting-growing period.

\begin{tabular}{|l|c|c|c|c|}
\hline Treatment & $\begin{array}{c}\text { Body } \\
\text { Weight }(\mathrm{g})\end{array}$ & $\begin{array}{c}\text { Feed } \\
\text { Intake }(\mathrm{g})\end{array}$ & $\begin{array}{c}\text { Weight } \\
\text { Gain }(\mathrm{g})\end{array}$ & $\begin{array}{c}\text { Feed } \\
\text { Conversion }\end{array}$ \\
\hline Control & $953^{\mathrm{a}}$ & $1514^{\mathrm{a}}$ & $911^{\mathrm{a}}$ & $1.66^{\mathrm{b}}$ \\
\hline En $1 / 0.05$ & $946^{\mathrm{a}}$ & $1605^{\mathrm{a}}$ & $904^{\mathrm{a}}$ & $1.77^{\mathrm{ab}}$ \\
\hline En $1 / 0.10$ & $945^{\mathrm{a}}$ & $1582^{\mathrm{a}}$ & $903^{\mathrm{a}}$ & $1.75^{\mathrm{ab}}$ \\
\hline En $2 / 0.05$ & $893^{\mathrm{a}}$ & $1568^{\mathrm{a}}$ & $851^{\mathrm{a}}$ & $1.84^{\mathrm{a}}$ \\
\hline En $2 / 0.10$ & $861^{\mathrm{b}}$ & $1505^{\mathrm{a}}$ & $819^{\mathrm{b}}$ & $1.84^{\mathrm{a}}$ \\
\hline
\end{tabular}

a-c means in the same column with different letters are significantly different $(p \leq 0.05)$.

Fayoum J. Agric. Res. \& Dev., Vol.19, No.2, July, 2005 
EFFECT OF ENZYME SUPPLEMENTATION ON PERFORMANCE..... 37

Body weight (BW): No significant increase in BW was found between the control group (953g) and each of En1/0.05 (946g), En1/0.1 (945g) and En2/0.05 (893g), while there was a significant decrease in BW between the control group (953g) En1/0.05 (946g), En1/0.1 (945g) and En2/0.1 (861g). However, no significant difference between En/0.05 and En/0.1 was found $(\mathrm{p} \leq 0.05)$.

Feed intake (FI): No significant difference in FI was found between the control group and any of the treated groups $(\mathrm{p} \leq 0.05)$.

Weight gain (WG): No significant increase in WG was found between control group (911g) and either of the following groups: En1/0.05 (904g), En1/0.10 (903g) and En2/0.05(851g). But a significant decrease was found in WG between the control (911g), En1/0.05 (904g), En1/0.10 (903g) and those fed En 2/0.1, which scored the lowest value, (819g). However, no significant difference between chicks fed En2/0.05 diet and those fed En2/0.10 diet was found $(\mathrm{p} \leq 0.05)$.

Feed conversion (FC): No significant difference in FC was found between chicks fed the control (1.66) and each of groups fed the En 1/0.05 diet (1.77) or En1/0.10 (1.75). On the other hand, there was significant difference $(\mathrm{P} \leq 0.05)$ between FC of the control group and chicks fed EN2/0.05 or 0.10 diets. However, no significant difference in FC was found between chicks fed the En2/0.05 diet and those fed the En2/0.10 diet $(p \leq 0.05)$.

Birds of all groups were switched to a finisher diet (19\%CP and 3200 Kcal ME/kg) from 29 to 42 days of age. The results are found in Table (4).

Table (4): The effect of enzyme supplementation on broiler performance during the finisher period.

\begin{tabular}{|l|c|c|c|c|}
\hline Treatment & $\begin{array}{c}\text { Body } \\
\text { weight }(\mathrm{g})\end{array}$ & $\begin{array}{c}\text { Feed } \\
\text { intake }(\mathrm{g})\end{array}$ & $\begin{array}{c}\text { Weight } \\
\text { gain }(\mathrm{g})\end{array}$ & $\begin{array}{c}\text { Feed } \\
\text { conversion }\end{array}$ \\
\hline Control & $1791^{\mathrm{a}}$ & $1695^{\mathrm{a}}$ & $837^{\mathrm{a}}$ & $2.03^{\mathrm{b}}$ \\
\hline En $1 / 0.05$ & $1764^{\mathrm{a}}$ & $1679^{\mathrm{a}}$ & $818^{\mathrm{a}}$ & $2.05^{\mathrm{b}}$ \\
\hline En $1 / 0.1$ & $1743^{\mathrm{a}}$ & $1648^{\mathrm{a}}$ & $798^{\mathrm{ab}}$ & $2.06^{\mathrm{b}}$ \\
\hline En $2 / 0.05$ & $1622^{\mathrm{b}}$ & $1671^{\mathrm{a}}$ & $729^{\mathrm{bc}}$ & $2.29^{\mathrm{a}}$ \\
\hline En $2 / 0.1$ & $1564^{\mathrm{b}}$ & $1606^{\mathrm{a}}$ & $703^{\mathrm{bc}}$ & $2.28^{\mathrm{a}}$ \\
\hline
\end{tabular}

a-c means in the same column with different letters are significantly different $(\mathrm{P} \leq 0.05)$.

Body weight (BW): No significant difference in BW was found between the control group and each of En1/0.05 or En1/0.10 groups. However, significant differences in BW were found between the control, En1/0.05, En1/0.10 groups and either of En2/0.05 and En2/0.10. fed groups. But no significant difference in BW was found between En 2/0.05 and En2/0.10 groups ( $\mathrm{p}<0.05)$.

Feed intake (FI): No significant difference in FI was found between the control group and any of the other groups $(\mathrm{p}<0.05)$.

Weight gain (WG): No significant difference in WG was found between the control group (837g) and either of En1/0.05 or En1/0.1 group ( $\mathrm{p} \leq 0.05)$. But a significant difference in WG was found between the control, En1/0.05, En1/0.1 and both En2 groups. However, no significant difference in WG was found among both of En2 groups ( $\mathrm{p} \leq 0.05)$.

Feed conversion (FC): No significant difference in FC was found between the control group (2.03) and both En1 treated groups. But a significant difference in FC was found between the control, En1/0.05, En1/0.1 (2.03) and

Fayoum J. Agric. Res. \& Dev., Vol.19, No.2, July, 2005 
H.F.A.Motawe, et al.

both En2 treated groups. However, no significant difference in FC was found between both En2 treated groups $(\mathrm{p} \leq 0.05)$.

Concering the whole period ( $0-42$ days of age), the results are found in Table (5).

Table (5): The effect of enzyme supplementation on broiler performance during the whole period.

\begin{tabular}{|l|c|c|c|c|}
\hline Treatment & $\begin{array}{c}\text { Body } \\
\text { weight }(\mathrm{g})\end{array}$ & $\begin{array}{c}\text { Feed } \\
\text { intake }(\mathrm{g})\end{array}$ & $\begin{array}{c}\text { Weight } \\
\text { gain }(\mathrm{g})\end{array}$ & $\begin{array}{c}\text { Feed } \\
\text { Conversion }\end{array}$ \\
\hline Control & $1791 \mathrm{a}$ & $3209 \mathrm{a}$ & $1749 \mathrm{a}$ & $1.84 \mathrm{bc}$ \\
\hline En $1 / 0.05$ & $1764 \mathrm{a}$ & $3283 \mathrm{a}$ & $1722 \mathrm{a}$ & $1.91 \mathrm{~b}$ \\
\hline En $1 / 0.1$ & $1643 \mathrm{a}$ & $3229 \mathrm{a}$ & $1701 \mathrm{a}$ & $1.90 \mathrm{~b}$ \\
\hline En $2 / 0.05$ & $1522 \mathrm{~b}$ & $3239 \mathrm{a}$ & $1580 \mathrm{~b}$ & $2.05 \mathrm{a}$ \\
\hline En $2 / 0.1$ & $1570 \mathrm{~b}$ & $3111 \mathrm{a}$ & $1522 \mathrm{~b}$ & $2.04 \mathrm{a}$ \\
\hline
\end{tabular}

a-c means in the same column with different letters are significantly different $(\mathrm{p} \leq 0.05)$.

In general, within each energy level, no significant difference was found between groups either supplemented with $0.05 \%$ or $0.1 \%$ enzyme in body weight, feed intake, weight gain and feed conversion.

The present results clarified that, the supplementation of such enzyme at $0.05 \%$ or $0.10 \%$ gave similar results by the diet containing normal or restricted energy levels, i.e. the enzyme-treated groups containing a low dietary oil level (En 1/0.05or En 1/0.1) gave similar body weight values as obtained from the control group (normal energy requirement). Whereas, starter/grower and finisher diets had $1.94 \%$ (from $3100 \mathrm{Kcal}$ to $3040 \mathrm{Kcal}$ ) and $4.38 \%$ (from 3200 Kcal to $3060 \mathrm{Kcal}$ ) reduction of $\mathrm{ME} / \mathrm{kg}(\mathrm{DM})$, respectively.

This energy restriction was done by the reduction of oil addition in the formulas, i.e. half oil requirement (En 1/0.05 and En 1/0,1) and no addition of oil at all (En 2/0.05 and En 2/0.1).

Attamangkune et al (2003) found that the supplementation of a commercial enzyme by the reduction of $2.5 \%$ of $3100 \mathrm{Kcal} \mathrm{ME} / \mathrm{kg}, 5 \%$ of 3150 Kcal ME/kg and $7.5 \%$ of $3200 \mathrm{Kcal} \mathrm{ME} / \mathrm{kg}$ during starting, growing and finishing periods, respectively, had no detereminal effects as compared with the control diet containing $3100 \mathrm{Kcal} \mathrm{ME} / \mathrm{kg}$ diet.

Elliot (2002) evaluated a commercial enzyme mixture (Amylase- Xylanaseprotease) and concluded that the mixture appeared to be effective in liberating energy with corn/soybean meal diet.

Mathlouthi et al (2002) found a significant difference between hens fed basal diet those fed and the treated diet with xylanase in egg mass, feed intake, feed conversion and change in body weight. In addition, with wheat and barley, they gave similar trend to the present results where, the addition of $1400 \mathrm{IU}$ xylanase $\mathrm{Kg}-1$ to low-energy diet values by $5.2 \%$ and $2.44 \%$ for wheat and barley, respectively.

Kidd et al (2001) fed a corn/Soya diet supplemented with enzymes to broilers chicks and found a significant reduction in feed conversion and mortality rate.

From the above mentioned results, it may be concluded that:

- No more than $0.05 \%$ from the mixture of Endo-1,4- $\beta$-xylanase and $\alpha$ amylase should be added to the corn/soya diet.

Fayoum J. Agric. Res. \& Dev., Vol.19, No.2, July, 2005 
EFFECT OF ENZYME SUPPLEMENTATION ON PERFORMANCE.....

- Similar body weight values obtained from restricted-energy diet by supplementation of enzyme without deleterious effect on performance as compared with the control diet.

- The supplementation of the target enzyme may reduce the dietary oil addition up to half its quantity.

- The reduction of oil in the diets may reduce the load of storing, mixing and rancidity of oils.

REFERENCES

Alam, M.J., Howlider, M.A.R., Pramanik, M.A.H. and Haque, M.A. (2003): Effect of exogenous enzyme in diet on broiler performance. Inter.J.Poult.Sci.2: 168-173.

Attamangkune, S., Plaiboon, A. and Trivuttanon, O. (2003): Effect of feeding Natuzyme Wet P on broiler performance. Poult. Res. And Develp. Center and Dep. of Anim. Sci., Kasetsart Univ., Kamphaengsaen, Nakhon Pathom, Thailand.

Bedfort, M.R. (1995): Mechanism of action and potential environmental benefits from the use of feed enzymes. Anim. Feed Sci and Tech. 53:145155.

Bedford, M. R. and Classen, H. L. (1992): Reduction of intestinal viscosity through manipulation of dietary rye and pentosans concentration is affected through changes in the carbohydrate composition of the intestinal aqueous phase and results in improved growth rate and feed conversion efficiency in broiler chicks. J. Nutr. 122: 560-569.

Benamrouch, S. (2002): A chemical and histological study on the effect of (14)-b-endo-xylanase treatment of wheat bran. J. Cereal Sci., 36: 253.

Brenes, A., Marquardt, R.R., Guenter, W. and Viveros, A. (2002): Effect of enzyme addition on the performance and gastrointestinal tract size of chicks fed lupin seed and their fractions. Poult. Sci. 81: 670-678.

Campbell, G.L. and Bedford, M.R. (1992): Enzyme applications for monogastric feeds: A review. Can. J. Anim.Sci. 72: 449-466.

Duncan, D.B. (1955): Multiple range and multiple F tests. Biometrics, 11: 1-42

Elliot, M.A. (2002): Enzyme use in commercial Layer production. Multistate Poult. Meeting, May 14-16, 2002. Indianapolis, IN., USA.

Huisman, J. and Tolman, G.H. (1992): Antinutritional factors in the plant proteins of non-ruminants diets. Butterworth Heinemann, Oxford, UK.

Jaroni, D., Scheideler, S.E., Beck, M.M. and Wyatt, C. (1999): The effect of dietary wheat middlings and enzyme supplementation II: Apparent nutrient digestibility, digestive tract size, gut viscosity and gut morphology in two strains of Leghorn hens. Poult.Sci. 78: 1664-1674.

Jorgensen, H., Xinquan, Z., Buch Knudsen, K.E., Eggum, B.O. and Zhao, X.Q. (1996): The influence of dietary fiber source and level on development of the gastrointestinal tract, digestibility and energy metabolism in broiler chickens. Br. J. Nutr. 75: 379-395.

Kidd, M.T., Morgan, G.W., Price, Jr.C.J, Welch, P.A. and Fontana, E.A. (2001): Enzyme supplementation to corn and soybean meal diets for broilers. J. Appl. Poult. Res. 10: 65-70.

Kocher, A., Choct, M., Porter, M.D. and Broz, J. (2000): The effect of enzyme addition to broiler diets containing high concentrations of canola or sunflower meal. Poult. Sci. 79:1767-1774.

Fayoum J. Agric. Res. \& Dev., Vol.19, No.2, July, 2005 
Mathlouthi, N., Larbier, M., Mohamed, M.A. and Lessire, M. (2002): Performance of laying hens fed wheat, wheat-barley or wheat-barleywheat bran based diets supplemented with xylanase. Can.J.Anim.Sci. 82:193-199.

Malathi, V. and Devegowda, G. (2001): In vitro evaluation of nonstarch polysaccharide digestibility of feed ingredients by enzymes. Poult. Sci. 80: 302-305.

Rotter, B.A., Friesen, O.D., Guenter, W. and Marquardt, R.R. (1990): Influence of enzyme supplementation on the bioavailable energy of barley. Poult. Sci. 69: 1174-1181.

Salobir, J. (1998): Effect of xylanase alone and in combination with $\beta$ glucanase on energy utilization and intestinal viscosity of broilers fed diets based on two wheat samples. Arch. Geflügelk. 62: 209-213.

Salobir, J., Pogorelec, R., Novak, B., Koman-Rajšp, Majca, Bogdanic, Malensek, Alenka, Salobir, K. and Orešnik, A. (2000): The effect of $\beta$ glucanase alone and in combination with xylanase on the nutritive vale of diets based on barley of low or high viscosity in broiler chickens. Arch. Geflügelk. 64: 231-236.

SAS Institute (1990): SAS $® /$ STAT User's Guide: Statistics. Version 6, $4^{\text {th }}$ Edit. SAS Institute Inc, Cary, NC, U.S.A

Speers, G.M. (2002): Enzymes improve nutrient utilization. Poult. Nutr. Conf., June 29-30, 2002, Cairo, Egypt.

Zhang, Z., Marquardt, R.R., Guenter, W. and Crow, G.H. (2001): Development of a multipurpose feed enzyme analyzer to estimate and evaluate the profitability of using feed enzyme preparations for poultary. Poult. Sci.. 80: 1562-1571.

Zhang, Z., Marquardt, R.R., Guenter, W., Cheng, J. and Han, Z. (2000): Prediction of the effect of enzymes on chick performance when added to cereal-based diets: Use of a modified log-linear model. Poult. Sci. 79: 1757-1766.

Yakout, H.M., Shehatta, M.M., Omara, M.E. and El-Ganzory, E.H. (2003): The effect of energy level on the response of Mandarah hens to enzyme supplemented diets. Egypt Poult. Sci. 23: 859-873.

Zyla, K., Koreleski, J., Swiatkiewicz., Wikiera, A., Kujawski, M., Piironen, J. and Ledoux, D.R. (2000): Effect of phosphorolytic and cell walldegrading enzymes on the performance of growing broilers fed wheatbased diets containing defferent calcium levels . Poult.Sci. 79:66-76.

Fayoum J. Agric. Res. \& Dev., Vol.19, No.2, July, 2005 
تأثير إضافة الإنزيم على الكفاءة الإنتاجية لكتاكيت اللحم

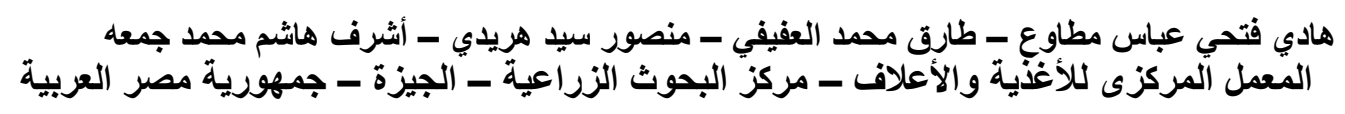

أجريت تجربـة لدر اسـة تأثثير مستحضـر إنزيم تجـاري من أصلـ بكتيري (باسلس سبتيلس)

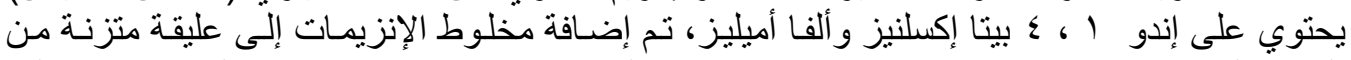

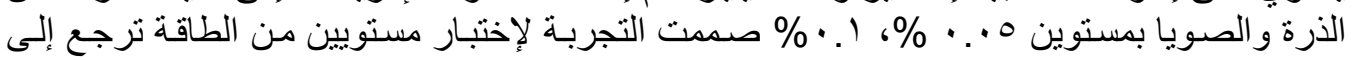

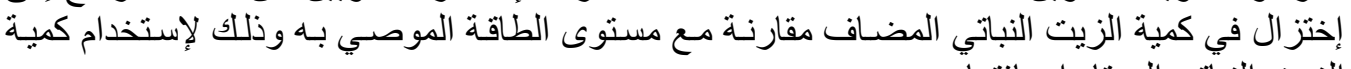
الزيت النباتي المعتاد إضافتها.

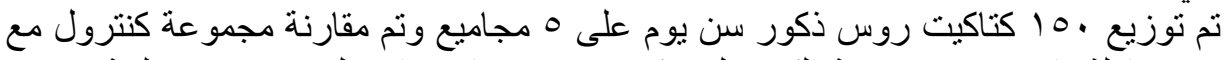

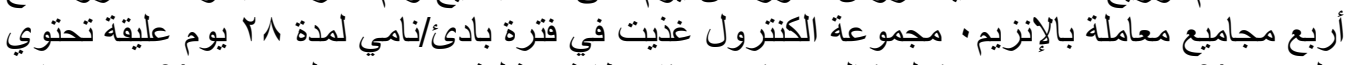

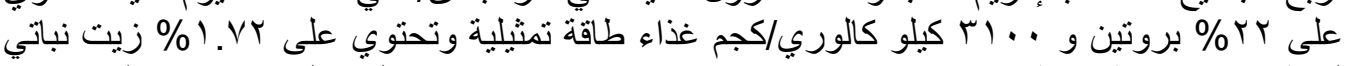

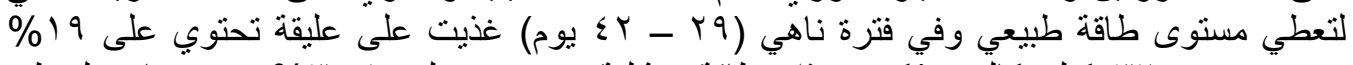

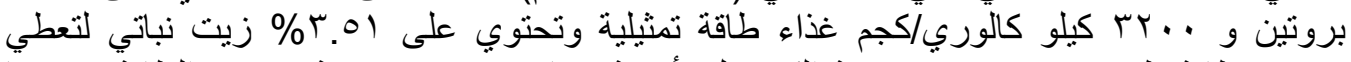

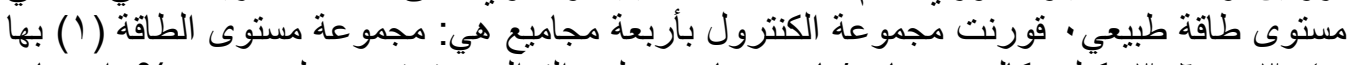

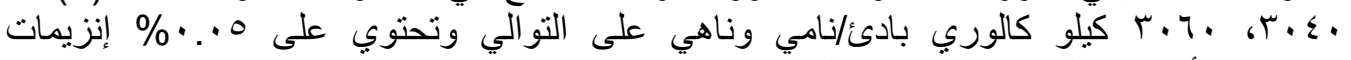

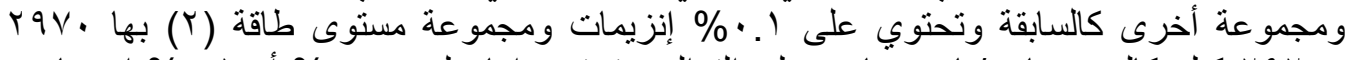

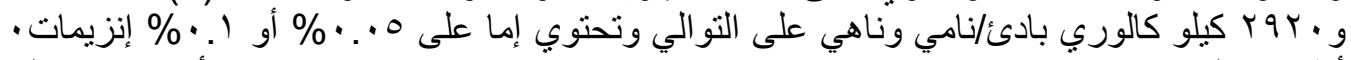

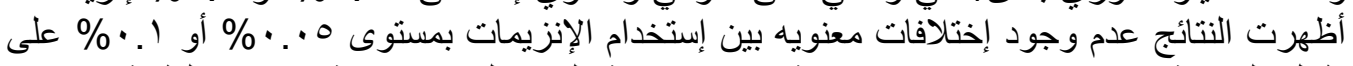

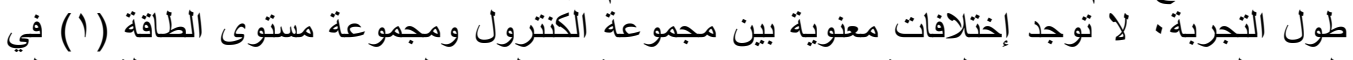

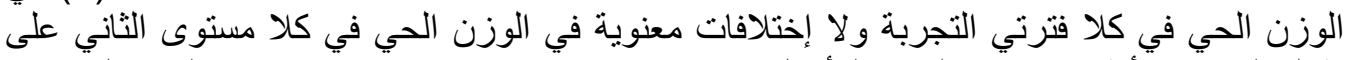

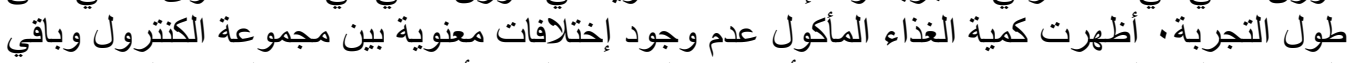

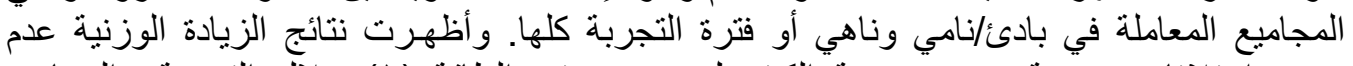

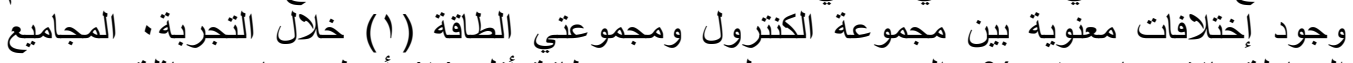

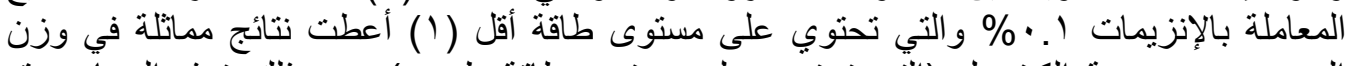

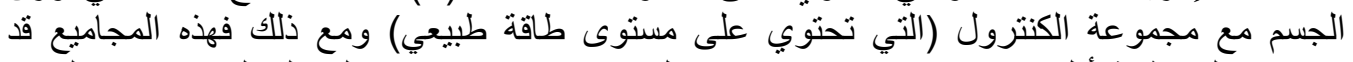

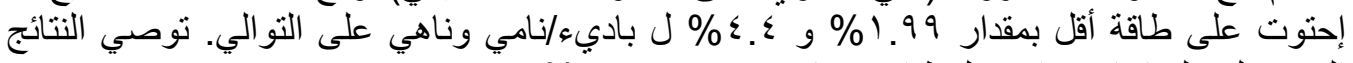

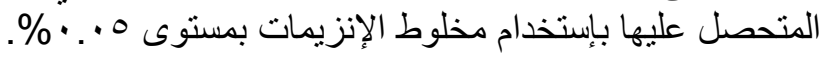

Fayoum J. Agric. Res. \& Dev., Vol.19, No.2, July, 2005 